Article

\title{
Against All Odds? Birth Fathers and Enduring Thoughts of the Child Lost to Adoption
}

\section{Gary Clapton}

School of Social and Political Science, University of Edinburgh, Edinburgh EH8 9YL, UK; gary.clapton@ed.ac.uk

Received: 4 March 2019; Accepted: 25 March 2019; Published: 29 March 2019

check for updates

\begin{abstract}
This paper revisits a topic only briefly raised in earlier research, the idea that the grounds for fatherhood can be laid with little or no 'hands-on' experience of fathering and upon these grounds, an enduring sense of being a father of, and bond with, a child seen once or never, can develop. The paper explores the specific experiences of men whose children were adopted as babies drawing on the little research that exists on this population, work relating to expectant fathers, personal accounts, and other sources such as surveys of birth parents in the USA and Australia. The paper's exploration and discussion of a manifestation of fatherhood that can hold in mind a 'lost' child, disrupts narratives of fathering that regard fathering as 'doing' and notions that once out of sight, a child is out of mind for a father. The paper suggests that, for the men in question, a diversity of feelings, but also behaviours, point to a form of continuing, lived fathering practices — that however, take place without the child in question. The conclusion debates the utility of the phrase "birth father" as applied historically and in contemporary adoption processes.
\end{abstract}

Keywords: birth fathers; adoption; fatherhood

\section{Introduction}

There can be an enduring psychological/attachment bond between the child and their biological father that is of significance both to the child and the father, whether the father is present, absent or indeed has never been known to the child (Clapton 2007, pp. 68-69).

In this paper I wish to further explore the connection to their children experienced by birth fathers ${ }^{1}$ in adoption. This exploration takes the form of a review and discussion of the existing literature relating to birth fathers plus the paper will draw upon developments in our understanding of how expectant fathers may develop attachments to their child as a means of the exploring the creation of the "enduring psychological/attachment bonds" found in the birth father literature. But first, a concise statement of context and clarity of definition is necessary.

\section{Adoption}

The traditional form of adoption in the U.K. has changed. Stranger (out of family) adoptions of healthy babies, voluntarily relinquished by natural parents has declined. In its place in a process that can be charted from the late 1980s, the majority of contemporary adoptions involve older children who have spent time in public care. These are children that have relationships with their parents, siblings and other family members. Many of these adoptions take place against the consent of the birth parents (O'Halloran 2015). This paper focuses on the biological fathers of the children of adoptions in the

1 The use of the term 'birth father' is explored in the latter part of this paper but for ease of flow and comprehension, the term will be used throughout to denote the biological father of the child given up for adoption. 
previous era of so-called "closed" adoptions referring to the sealing of records and practice of secrecy relating to a child's familial origins (Ryburn 1995). These closed adoptions are distinct from the more open adoptions of today when adoptive parents, adopted children and birth families are more likely to have some form of contact with each other, either before, during or after the adoption has taken place. $^{2}$ The marked increase in the practice of open adoption and decrease in closed adoptions can be dated roughly from the end of the 1980s (Clapton and Clifton 2016). The focus of this paper involves the closed adoptions prior to this period when, invariably, after the adoption, birth parents knew little or nothing about their child.

\section{Birth Parents and Adoption}

Research, in decreasing degree of attention has focused on adopted children, adoptive parents and families, birth mothers and birth fathers (Clapton 2018). The existing research on the impact of adoption on birth parents demonstrates the extreme and longstanding implications for them of the loss of a child to adoption. Most of this literature concerns birth mothers. The main UK studies (Bouchier et al. 1991; Howe et al. 1992; Hughes and Logan 1993; Logan 1996) concluded that there are continuing negative consequences for many birth mothers' physical and mental health and well-being. Research, especially in Australia, has characterised the birth mother experience as that of disenfranchised grief related to the continuation and domination of maternal feelings towards the child (Robinson 2018). There are far fewer studies of birthfathers.

\section{Birth Fathers and Adoption}

In February 2019, I entered the words "birthfathers" and "adoption" into Google and up came the message "Did you mean "birth mothers" adoption?". Well, no I did not. See Figure 1.

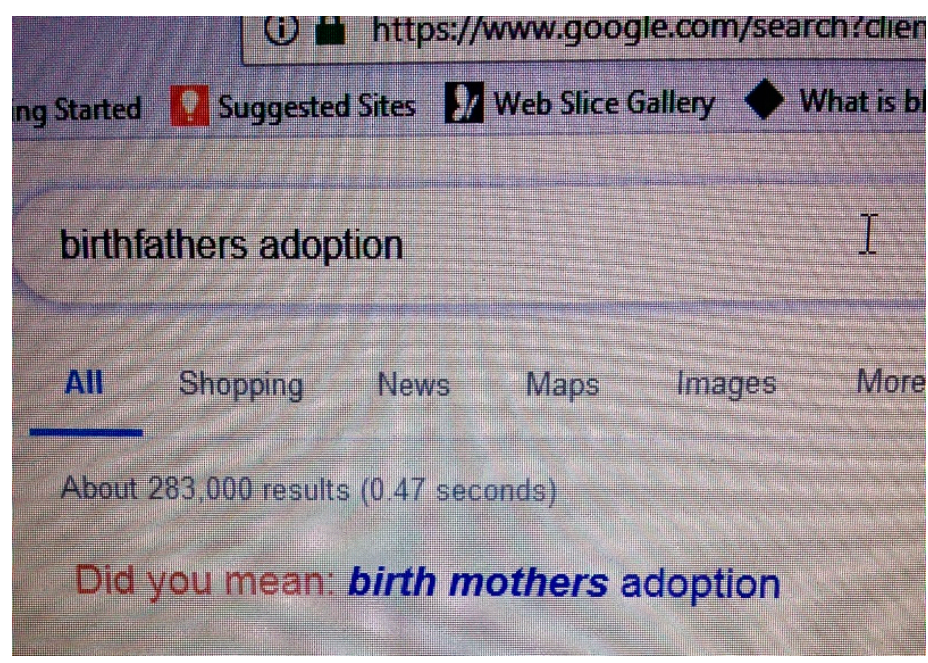

Figure 1. Google and birthfathers.

Working out where the (biological) father fits in adoption is not only problematic for Google. The nature of fathering and fatherhood is a relatively new field of study compared to that of mothers. Much has been done in the last few decades to develop our understanding of how men become fathers, the role of fathers and the unique contribution that they can make to the life of a child (Lamb 2010). However, an equivalent degree of scholarship on birth fathers in adoption does not

2 This is not to suggest that adoption is a one-off event. Adoption is a life-long process for all (Gediman and Brown 1991, p. 254), rather it is to acknowledge efforts to achieve continuity of connections between birth families and adoptive families in contemporary adoptions. 
exist ${ }^{3}$. This may be because of a long-held view that "It sometimes appears that we have actually been guilty of contributing to a myth that. suggests that a child born out of wedlock has only one natural parent" (Anglim 1965, p. 340) Forty-five years later, Coles refers to what he terms "the common view that birth fathers were not there (at pregnancy and birth), so how could they possibly have an emotional response?" (Coles 2010, p. 25). Research that has raised the possibility of the birth father who has had no or little physical connection with their child, having paternal thoughts and emotions problematises such lasting notions of birth fathers, contributes to our developing insights regarding fathers as a whole and can be said to be part of a general 'catching up' about fathers that has addressed a traditional emphasis on mothers, and a lack of attention as to how men perceive fatherhood (Clarke and Popay 1998). A significant aspect of fatherhood research is that it has focused on what men do (or not) with their child (Ranson 2015) with less work on what it means and feels like to be a father. 'Hands-on', expressive behaviour is seen as the moment when men come into their own as fathers with their children (Brannen and Nilsen 2006). This makes the case of birth fathers who feel for their child yet have had not such experience of contact worthy of study. As will be seen there is a small collection of studies, some individual accounts, magazine and internet contributions, and knowledge that can be gleaned at second-hand via accounts of adopted people meeting their fathers that sheds light on the relatively secret, inner lives of birth fathers. As such the trajectory of our knowledge of birth fathers mirrors how our understandings of fathers started further back in the field from mothers. In the words of birth father Ward's counsellor and intermediary "Birth fathers are about thirty years behind birth mothers in gaining their voices in the adoption process" (Ward 2012, p. 198).

For decades birth fathers have been talked of as shadowy (Mason 1995), shadowy figures (Rawles 2003; Hughes 2015) phantom fathers (Passmore and Chipuer 2009), and invisible men (Coles 2010). Twenty years ago in relation to later-life contact between adopted people and their families of origin, March (1995) counselled that to "focus only on the adoptee-birth mother contact is an injustice too often in the current adoption literature" (p. 104). Unfortunately this advice on the need for further attention has not been taken up in the main, e.g., birth fathers remain overlooked in the adoption literature in general (Neil 2017; Siegel 2017). Adoption-related stories and fiction for children repeat the absence of a biological father. In the classic children's story designed for adopted children, The Mulberry Bird (Brodzinsky 2013), Mother Bird's struggles are detailed: her struggle to feed her baby bird; the storm that drives her to seek counsel from the wise Owl; her visit to the seashore birds, who welcome the baby bird into their soft, safe nest. But one figure is all but missing. The male who fathered baby bird is mentioned only in passing. Mother Bird "noticed that some of the other mothers had father birds to help them. Her baby's father had flown away long before she built her nest and laid the pale blue egg." (p. 11).

Our lack of knowledge-and misunderstandings—stands in contrast to some interesting facts on the ground. These are that:

More British men than ever before are trying to track down their adopted kids. Over 1000 birth fathers are officially registered with adoption-contact agencies and hundreds more are believed to be searching for their children independently (Rawles 2003).

According to Australian researchers, Passmore and Chipuer (2009), the little we know of the search behaviour of birthfathers questions any notions of them being marginal or disinterested. In one of the first pieces of birth father research, a survey of 125 American birth fathers, $96 \%$ had considered searching for their relinquished child, and $67 \%$ had actually searched (Deykin et al. 1988). Similar results have been found in Australia where Cicchini (1993) found that $77 \%$ of the thirty birthfathers in his study had taken active steps to seek information about, or make contact with, their child. Clapton (2003) found that nearly $90 \%$ of the thirty Scottish and English birth fathers in his study desired some contact with their child. Twenty out of the twenty seven fathers in the study by Passmore

3 The adoptive father is equally under-researched (Siegel 2017). 
and Coles had actively searched (Passmore and Coles 2009). The most recent account of birth father experiences includes the information that nine of the twelve interviewed were searching for their child (Kenny et al. 2012). Applications for information and contact registers are another means of locating and measuring birth father interest. Browning cites New Zealand figures relating to birth parent applications for identifying information relating to their children and these indicate that birth fathers made up 12\% of these (1034/8095) (Browning 2005, p. 4). Elsewhere the Adoption Contact Register for Scotland has a very similar proportion-250/2274-eleven percent of birth fathers registered as seeking contact with their children (Birthlink 2019. personal communication). The number of birth fathers on the Adoption Contact Register for England and Wales is also similar at 1025 out of a total of 10547 birth parents registered (HM Passport Office 2019. Personal communication) There are many reasons for the disproportions (in relation to birth mother expressions of interest). These include men's reluctance to express emotions and their names not being on the birth certificate (Coles 2010) but suffice to say that these statistics add to the cumulative impression that a sizable amount of birth fathers, contrary to the impression of marginal figures, have an enduring interest in their child. So whilst it is acknowledged that most of the men in the above studies were recruited via one form or another of a means to register for news of their child's welfare and hope for a meeting, the repeated refrain of interest in their child is unignorable.

What do the existing works tell us of being a birth father? Deykin et al. (1988), Cicchini (1993), Clapton (2003), Witney (2004), Triseliotis et al. (2005), Passmore and Coles (2009) and Kenny et al. (2012) have in common the finding that some birth fathers have been, or indicated a wish to be, in contact with their child. What might drive this?

\section{Enduring Love, Enduring Fatherhood}

"The adoption rubbed me out legally but not emotionally" (in Clapton 2003, p. 122).

In Author's study of thirty birth fathers, it was found that after the adoption of their child, whilst nearly half of the men experienced an eventual reduction of feelings of immediate distress, others reported that things either did not get better or that such feelings had intensified. Many of these feelings convey feeling like a father:

As time went by when I'd see a child, I'd think B-must be that age. This feeling has become more pronounced as I've got older. There has never been a time when I was completely free (Clapton 2003, p. 128).

The child was never out of mind for most of these men, on birthdays and Xmases and at "any quiet moment" In The Birth Father's Tale Ward (2012) writes of his son being "never far from my mind", that "he's shaped my life", and wanting to tell him "that there's been an invisible hand over him, wishing him well" (p. 3). Birth fathers also speak of rituals of observance and devotion:

Every year when his son's birthday comes around, John buys a bottle of whiskey, goes into a dark room and drinks till he drops. He's been observing this ritual for as long as he can remember. 'I've been pining for my son all my life. There's not a day goes by when I don't think about him' (in Rawles 2003, p. 80).

The men in the Passmore and Coles study (2009) send yearly birthday and Xmas cards to the adoption agency. Others attend the adoption agency every year for an annual up-date on their child's life. Some have left money in their wills to their adopted-out child (Browning 2005).

Much of this, it has to be noted, involves men that never saw or touched their child. Ward (2012) never held his child or saw him yet: "If you spend over thirty years starved of a person, you dearly love, devoid of dialogue with him, all that exists is thinking, writing and imagining" (p. 201). For those that did have sight or touch the loss remains palpable for decades:

The one thing I remember most is the smell, like a new-born smell-comes back now. I suppose that stays with you all the time. It's immediate. (in Witney 2004, p. 56).

Ward and others speak directly of paternity, specifically "My frustrated parenthood" (Ward 2012, p. 200) and “You don't stop being a father just by signing away the adoption 
papers" (in Rawles 2003, p. 81). The adopted-out child is spoken of as lost ("a lost son" Passmore and Coles 2009, p. 8), and a missing family member "Her absence from our family leaves a hole in my heart. I wish we could be reunited" (Kenny et al. 2012, p. 83). Cicchini (1993) found considerable evidence of feelings of responsibility. This is echoed elsewhere when fathers speak of having "abandoned their charge" (Clapton 2003, p. 133).

Expressions of parental feelings are intense in many of the accounts. The top reason for searching in Cicchini's study was "I have a sense of responsibility for my child" (1993, p. 19). The associated motivation for assurance as to their child's welfare is present as the highest-rated of search motives in Passmore and Coles (2009).

These fathers identify an ambivalence at the heart of the matter when they acknowledge that their feelings exist in spite of having no experience of day-to-day care, and "have difficulty in responding truthfully when asked how many children we have" (Coles 2010, p. 44). And they also grapple with their identities: "I didn't bring her up, her dad did, I'm her father" (in Clapton's study (2003, p. 165)

The research has also identified incidences of fathers conforming to some of the more popular stereotypes of men who discover they are to become fathers: "I disappeared to London hoping no one would find me. I was distraught" (Witney 2004, p. 55). Whilst it follows that larger and more random studies of birth fathers might reveal greater evidence of such behaviour, present in the accounts that we have are mostly feelings of connectedness (with the child) (Coles 2010), "emotional and psychological ties" (Rawles 2003, p. 81) and a pervasive vein of attachment or bond, albeit a one-way street: " ... there is evidence of a constellation of feelings and behaviours that indicate the development of a sense of fatherhood" (Clapton 2003, p. 83).

What then are we to make of these beliefs in, and feelings of, fatherhood? Are bonds with the child a result of maturation (Cicchini 1993), guilt (Mason 1995; Passmore and Coles 2009), shame over abandonment (Coles 2010), a combination of all these? Ainsworth makes a difference between relationship bonds which are dyadic, and affectional bonds which can be experienced by the individual in absentia of the other (Ainsworth 1991, p. 37). Are these what birth fathers feel? Whilst it has already been acknowledged that our knowledge of birth fathers is scant and that the research to date has not drawn on random samples, yet there is sufficient repetition of testimony to feelings of fatherhood to warrant a deeper enquiry into the possible source of the feelings of paternal-ness expressed throughout the existing accounts. In the face of normative expectations that fathers provide and care and that the essence of a good father is 'being there' (Plantin et al. 2003), from where might birth father feelings emerge, and what sustains them in the face of never having 'been there' for their children? A small group of recent studies that delves deep into fathers' emotions, their sources and creation, might shed greater light.

\section{The Creation and Maintenance of Paternity}

Condon et al.'s (2013) study of first-time fathers' ante-natal attachment begins with the pertinent observation that "in the attachment research literature, it is largely behaviours which are the focus of assessment methodology" (p. 15). This is germane because, in the case of birth fathers, aside from the various commemorations and rituals referred to above, there are no behaviours to observe relating to interactions between fathers and children. Condon et al. go on call for a "holistic approach to the understanding of the parent-infant relationship" that requires "consideration of both parental subjective experience as well as behaviour" (ibid. emphasis added). Paternal attachment is a "feeling state", and they conclude that the findings from their analysis of expectant fathers' self-reports suggest that "a father's attachment may not stem solely from actual interaction with the neonate or infant" but "Rather, the predominant contribution may stem from some underlying 'capacity' to form an attachment bond which is activated in fantasy before the baby is even born" (p. 25). The writers

4 The dad or father question is discussed below. 
speculate that such attachment might reflect "a kind of 'commitment' to the couple relationship" (ibid) - in the case of the birth fathers' adoptions that we know about, the majority of cases involved young people in relationships with each other, though, it has to be said, by no means were the majority of pregnancies planned (Clapton 2003). The conclusions of Condon et al. therefore problematise fixed notions of "being there" and "hands-on" as the definitions of how bonds are formed between fathers and their children. In other specific instances e.g., men absent as soldiers; research has shown a sense of fatherhood thrives after the birth without ever having seen the child (Bell 2008; Turner and Rennel 1995). Notwithstanding that the men in the latter studies were in expectation of a future relationship with their child, the fact that in some of the birth father cases, the men were disabused of this expectation, makes signs of attachment in birth fathers ever more arresting.

Given the latter proviso about thwarted expectations and the evidence of mixed reactions to the pregnancy, nevertheless, it can be said that, whether they embraced the role or not, the birth fathers in the studies were expectant fathers. A second study that may be of use in understanding and appreciating birth fathers' paternal bonds is the enquiry by Edelstein et al. (2015) into hormonal changes in expectant fathers. The researchers find hormonal changes in expectant fathers that they suggest are associated with the development of fatherhood (p. 322). In her discussion of the "neurochemistry of fatherhood", Machin covers the same territory of hormonal changes and makes a similar observation concerning the expectancy stage of fatherhood (Machin 2018). Could such changes also be at work for birth fathers in amongst the mix of conflicting emotions during the pregnancy and birth, whether or not they were present, banned or took themselves away?

Remaining with expectant fathers, the systematic review by Baldwin et al. (2018) notes that for many new fathers the transition to fatherhood was the "best experience" in their lives (p. 2139) and goes on "The ability to father a child made men feel like they were accomplishing an important phase in their lives" (ibid.) There is some evidence of the pleasure of having fathered a child and looking forward to a familial relationship in the birth father literature (Clapton 2003; Witney 2004; Coles 2010) Whether or not wholly embraced, and by no means all did so as noted above, the majority of the birth fathers that we know of experienced a transition to fatherhood that was to make and retain a decisive impression on their lives.

Lastly of this small group of studies on expectancy and fathers, although a small sample was used, Khambatta's study of eight birth fathers using a 'Parent Attachment Questionnaire' of her own devising (Khambatta 2011), found that "biological fathers in the current sample consider genetic ties to be an important component of interaction with their child(ren), and an even greater element of their attachment relationships with the genetic child(ren)" (p. 35).

All told then, it is suggested that developments in our understanding of how men transition to fatherhood posits an empirical basis for birth fathers' enduring paternity or paternal-ness and their attachment to their children. This seems to be a combination of genealogical, biological, psychological and emotional factors. But do they have a "right to call themselves a father" (Coles 2010, p. 156)? It seems that we have gone a long way around to arrive at what most people would acknowledge, and certainly most people involved in adoption do-the basic truth that "all adopted persons have two mothers and two fathers" (ibid. p. 186). In a recent paper on adoption reunions Clapton (2018) argued that our developing understandings of the experiences of reunions leads to the conclusion that hierarchies of family in adoption are unhelpful. That is, the notion of equating the family with those that have done the work of raising the adopted child as the primary one, and the birth family as secondary-and provisional or contingent-was problematised by reunions between adopted people and their families of origin: reunions with birth fathers (and those with siblings) both disrupt any fixed essentialist ideas of kinship between adoptive people and birth mothers, but also poses the question, as Hughes does, of the helpfulness of ideas of kinship hierarchies (Clapton 2018, p. 41).

The present paper applies this notion of a more flattened, less hierarchical approach to relations between adopted people and their fathers whether the birth father is in the life of the child or not. 


\section{Who's the Daddy?}

California law, like nature itself, makes no provision for dual fatherhood Michael H. v. Gerald D. 1989, p. 118 quoted in (Hubin 2014, p. 76)

Hubin (2014) however goes onto note that "There is nothing in nature that declares that a child cannot have more than one legal or social male parent" (p. 79). He counters with difference between genetic parentage and social parentage, the key determinant of 'who's the daddy', being the father who has the "responsibility-for-dependent-life" with the "agent", the father holding "a special duty to promote the well-being of that dependent life and, a fortiori, to prevent its suffering" (p. 86). Hubin approvingly quotes Mahowald:

A real mother, then, is first and foremost a woman who cares for a child, from any state of development, until the child no longer needs that care. A real father is a man who does the same when he can, i.e., after the child is born. ... it is hard to see how genetic ties alone ever provide an adequate basis for defining real mothers or real fathers (Mahowald 2000, p. 526 cited p. 84).

This harks us back to the distinction made between birth fathers and adoptive fathers with the latter the ones 'being there' ("real fathers are those who are there", Gadd, birth father, (Gadd 2003)). However, Hubin concludes that the rise of various and differing family formations in the 20th century has seen increasing involvement of what he terms "genetic fathers" in the lives of children being raised by the child's mother and her husband, the non-biological father (p. 89). For now it is worth noting that such involvement of two fathers in the life of a child is very clearly the case in the 21st century adoptions from care. Family practices in such adoptions can blur binary constructs of "real" father and "genetic" father and I return to this at the conclusion of this paper.

So although it might seem uncontroversial that "father" can be used interchangeably in many of the more fluid of contemporary Western family practices ${ }^{5}$, the title "dad" still seems sacrosanct, fit only for one man. But what of the outpouring of parental feelings documented in the birth father literature, the dedication to their children's welfare, the constant references to affection, bonds and enduring love, and the activities designed to achieve a reunion with their "lost son" (Brown 2015), or missing family member? ${ }^{6}$. It is true that to a man, birth fathers have repeatedly acknowledged that "their child's adoptive father is the "dad" (Passmore and Feeney 2009, p. 103). Some men go as far as to say that to call themselves anything more, or have a greater or equivalent claim on paternity as the adoptive father would be discreditable: "For me to act as your father would be inappropriate and morally wrong" (Trinder et al. 2004, p. 67). But yet, a deeper delving in our (albeit scanty) knowledge of birth fathers reveals less conviction, greater disruption to the accepted definition, more blurring and hesitancy over fixed categories of "dad" and "father". Additionally, the accounts of adopted people and birth fathers relating to later-life reunions also give pause for greater consideration of what we call the fathers in adoption. On a first reading, in the birth fathers accounts, there seems little debate about being and feeling like fathers (though Ward lists over ten terms from "blood to "proper", (Ward 2012, p. 112)). And it is also clear that irrespective of objective reality, many of the birth fathers refer to their son or daughter using the possessive-writing about counting off the years, Ward is typical: "Three years later when my son was nine" (2012, p. 155 emphasis added). In response to a question about what he was seeking one day, one of the respondents in Author's study of thirty birth fathers confessed: "The simple reason is that she's not mine at this moment in time. At this moment in time—-probably the wrong thing to say—she's on loan to someone else" (2000, p. 258). Birth fathers' attitudes to possible reunions and actions in reunion share a variety of 'takes' on the relationship. Reunions have the effect of making corporeal the father-child relationship between birth fathers and

5 It must be noted that the debates and controversies visited in this paper are very much anchored in Western culture, especially the anglophone world of the UK, USA, Canada, Australia and New Zealand all of which societies have experienced similar trends and developments in adoption. Elsewhere in the majority world, the issue of hierarchical distinctions and roles in fatherhood and fathering can be less controversial.

6 See Hughes (2015) in which the word "reunion" as applied to birth fathers in adoption is problematised. 
their children. The reunion literature certainly shows a spectrum of views following later-life contact. For adopted people, one woman declares: "you can't be my father, you are my biological father and there's no getting away from that, but you are not emotionally my father and you didn't bring me up" (Trinder et al. 2004, p. 66). Another (about her birth father), “ . . even though someone conceived me and gave birth to me, those people can never be a parent and I've told them that. They physically can't be a parent because there's no history there." (Passmore and Chipuer 2009, p. 98). The seven adopted people in the latter study were clear that their relationships with their birth fathers ranged from "no relationship, to distant relative, to close friendship". After a reservation about small sample size, Passmore and Chipuer go on to note that "It is interesting that none of the adoptees regarded it as a father-daughter relationship" (ibid, p. 100). At the other end of the spectrum there are instances of a conferring of both the title of dad and role by the adopted person: "me dad" as one person says in Trinder et al.'s Adoption Reunion Handbook (2004, p. 62). Another refers to his birth father as "my old man" (Clapton 2000, p. 172) and another in the study by Hughes (2015) is "happy to call her biological father "dad" and herself "his girl"" (p. 163). Whilst it is difficult to estimate prevalences it is clear that "father" far outweighs "dad" in the accounts of adopted people, for example, in Browning's study only one of the twenty adopted people uses the term "dad" to describe her birth father.

And yet, as far as birth fathers are concerned, after contact and establishment of a relationship, Clapton (2003) notes that in some cases of the birth fathers in his study, "there were indications that the two roles of biological and social father were converging during contact and the subsequent relationship with the adopted child" (p. 176). For most of the birth fathers we have knowledge of such a convergence may be a pipe dream because "They are aware that their child will not view them as their father. However, they still identify their child as their own but the label of father versus birth father is difficult for them to establish as their own" (Christensen 2017, p. 22). In a similar vein to the expressions of possessiveness referred to above, in his blog, on meeting with his (adult) son Brown (2015) writes of his relief "to know that he had been well cared for" and although he meets with his son's adoptive parents, there's a sense of his son being returned to him.

Thus there are many points along a spectrum of lived paternal-ness from no grounds to be called father to many reasons $t$ to have the title and so what can be suggested is that the role of the father is disrupted and rendered more fluid in adoption. Such ambiguity is crystallised in disputes and debates over terminologies.

\section{Conclusions: It's Only Words}

Words matter. Yet it remains the case that the vast majority of the literature speaks of birth mothers and fathers and adoptive mothers and fathers. The distinction has been made hesitantly: "Birth mother or father" acknowledges the associated reproductive relationship and in the absence of a term to best describe the relationship, would seem the best among the alternatives available" (Browning 2005, p. 7). ${ }^{7}$

In The Birth Father's Tale, Ward (2012) worries away at the word "birth": "why birth son? Why not just son? Oh, I see. Well that's how we are known in the adoption business isn't it? I'm his birth father and he's my birth son" (p. 29). He visits the names discussion. Is he "Father Number One, Father One?" and decides that "Our society still has no words for mothers and fathers who surrender their child for adoption (pp. 192-93). Further discrepancies are apparent in evidence which shows the widespread lack of use of the prefix "birth" in accounts of meetings and contact between adopted people and non-parent members of their birth families. For example, in Author's study of the long-term outcomes of reunions (2018), none of the accounts relating to sibling contact of any of the forty adopted people used the phrases "birth brother" or "birth sister", in fact one respondent went out of her way to eschew

7 Understandably, given the relative maturity of the birth mother research, the debate about maternal nomenclature emerged earlier (Affleck and Steed 2001). This too has not been settled (Gair and Moloney 2013). 
what she regarded as demeaning prefixes: "I feel so lucky to have found an amazing brother and sister. We don't like to say $1 / 2$ half brother and $1 / 2$ half sister" (p. 10).

Phrases matter too. And perhaps the phrase that is most problematised in exploring the experiences of birth fathers (and birth mothers) is "as if born to". Adopted children are treated in law "as if born to" the adoptive parents in adoption legislation (see The Adoption and Children Act 2002, England and Wales, s. 67). It is clear from the accounts of the birth fathers we know of that, this is patently not felt to be the case. Furthermore, the accounts of adopted people in the literature convey the obvious appreciation that whilst they have a mother and father, they were not born to them (Beauchesne 1997). ${ }^{8}$

Yngvesson (2007) challenged the long-standing viewpoint in adoption that "a child can only be one thing or the other and whose adoptability requires the cancellation of one identity, so that identity can be replaced by another" (p. 569). What if this argument were applied to the fathers in adoption? When both adoptive father and birth father can say that they have a daughter, what if that daughter were enabled to comfortably say that she has not one father but two? (with the proviso when necessary that only one would be "dad").

Such clarity would put an end to the wrangling over nomenclature for birth parents e.g., "biological", "natural", "blood", "original", 'first' have all been used. The most popular titles continue to be "birth mother" or "birth father" (albeit that the discourse is dominated by academics and professionals). That is to say, that from now on, could an adopted person being permitted to contentedly say that they have two fathers, without one being termed "the birth father"? After all, today's adopted children, adopted at the age of four or five or older, will grow up in the full knowledge, derived from practical experiences, that they have another father 'out there'. In relation to these contemporary adoptions, where there might very well be up to two mums and two dads in play (Jones and Hackett 2012), it seems unnecessarily divisive and inimical to a child's welfare and interests to insist on familial hierarchies.

In conclusion, the agonies of birth mothers whose children were adopted before the 1990s have been documented (see for example, Charlton's Still Screaming, (Charlton 1998)) and those of birth fathers from the same period (Cicchini 1993; Clapton 2003; Witney 2004). Increasingly, the despair, anger and traumas of today's fathers and mothers whose parental rights have been forcibly extinguished and their children adopted are being charted (Clifton 2012; Lewis and Brady 2018; Smeeton and Boxall 2011). This paper has argued that dropping the 'birth' from fathers and mothers of children adopted out in the era of 'closed' adoptions is worth debate. The debate is all the more pressing for today's mothers and fathers involved in the adoptions of the children that have known them and may know them again in later life. It is suggested that the words birth mother and birth father are not only anachronisms but are demeaning and perpetuate a falsehood that the adopted children had only a biological or genetic connection to them. In such cases, a maintenance of the 'as if born to' principle flies in the face of reality for all concerned, but also, as we have seen with the studies of birth fathers discussed in this paper, discounts the fathers who are legally rubbed out but hold their child in mind daily for the remainder of their lives-against all odds.

Funding: This research received no external funding.

Conflicts of Interest: The author declares no conflict of interest.

8 During the debate on the Adoption and Children Bill (England and Wales) in 2002, the British Association of Social Workers called for the removal of the phrase 'as if born to' because the wording "unhelpfully implies a legal pretence or fiction which is at odds with the facts" https://publications.parliament.uk/pa/cm200102/cmstand/special/st011128/11128s01.htm (accessed on 2 March 2019). 


\section{References}

Adoption and Children Act. 2002. Adoption and Children Act. Available online: https:/ /www.legislation.gov. uk/ukpga/2002/38/contents (accessed on 21 March 2019).

Affleck, Marian, and Lyndall Steed. 2001. Expectations and experiences of participants in ongoing adoption reunion. American Journal of Orthopsychiatry 71: 38-48. [CrossRef]

Ainsworth, Mary. 1991. Attachments and other affectional bonds across the life cycle. In Attachment across the Life Cycle. Edited by Colin Murray Parkes, Joan Stevenson-Hinde and Peter Marris. New York: Tavistock/Routledge.

Anglim, Elizabeth. 1965. The Adopted Child's Heritage-Two Natural Parents. Child Welfare 69: 339-43.

Baldwin, Sharin, Mary Malone, Jane Sandall, and Debra Bick. 2018. Mental health and wellbeing during the transition to fatherhood: a systematic review of first time fathers' experiences Mental health and wellbeing during the transition to fatherhood: A systematic review of first time fathers' Experiences. JBI Database of Systematic Reviews and Implementation Reports 16: 2118-91. [CrossRef]

Beauchesne, Lise. 1997. "As If Born to": The Social Construction of a Deficit identity Position for Adopted Persons. Ph.D. dissertation, Wilfrid Laurier University, Waterloo, ON, Canada.

Bell, Irvin. 2008. The Life of Johnny Reb: The Common Soldier of the Confederacy. Lewisberry: Charter Press.

Birthlink. 2019. Adoption Contact Register for Scotland birth parent registrations. Personal communication.

Bouchier, Pat, Lydia Lambert, and John Triseliotis. 1991. Parting with a Child for Adoption: The Mother's Perspective. London: BAAF.

Brannen, Julia, and Ann Nilsen. 2006. From Fatherhood to Fathering: Transmission and Change among British Fathers in Four-generation Families. Sociology 40: 335-52. [CrossRef]

Brodzinsky, Anne Braff. 2013. The Mulberry Bird. St Paul: Perspectives Press.

Brown, Rob. 2015. The Lost Son. Available online: http://www.fathersnetwork.org.uk/the_lost_son (accessed on 21 March 2019).

Browning, Julee. 2005. Blood Ties: The Labyrinth of Family Membership in Long Term Adoption Reunion. Ph.D. thesis, Massey University, Albany, New Zealand. Unpublished.

Charlton, Lynn. 1998. Still Screaming. Manchester: After Adoption.

Christensen, Kayla. 2017. Birth Parents: Blogging the Emotional Journey through Adoption. Available online: https:/ / sophia.stkate.edu/msw_papers/718 (accessed on 21 March 2019).

Cicchini, Michael. 1993. The Development of Responsibility: The Experience of Birth Fathers in Adoption. Perth: Adoption Research and Counselling Service.

Clapton, Gary. 2000. Perceptions of Fatherhood: Birth Fathers and Their Adoption Experiences. Ph.D. thesis, University of Edinburgh, Scotland, UK. Unpublished.

Clapton, Gary. 2003. Birth Fathers and Their Adoption Experiences. London: Jessica Kingsley.

Clapton, Gary. 2007. The experiences and needs of birth fathers in adoption: What we know now and some practice implications. Practice 19: 61-71. [CrossRef]

Clapton, Gary. 2018. Close Relations? The Long-Term Outcomes of Adoption Reunions. Genealogy 2: 41. [CrossRef]

Clapton, Gary, and John Clifton. 2016. The birth fathers of adopted children: Differences and continuities over a 30 year period. Adoption \& Fostering 40: 153-66.

Clarke, Sue, and Jennie Popay. 1998. "I'm just a bloke who's had kids": Men and women on parenthood. In Men, Gender Divisions and Welfare. London: Routledge, chp. 8.

Clifton, John. 2012. Birth Fathers and Their Adopted Children: Fighting, Withdrawing or Connecting. Adoption $\mathcal{E}$ Fostering 36: 43-56.

Coles, Gary. 2010. The Invisible Men of Adoption. Melbourne: Mermerus Books.

Condon, John, Carolyn Corkindale, Philip Boyce, and Elizabeth Gamble. 2013. A longitudinal study of father-to-infant attachment: antecedents and correlates. Journal of Reproductive and Infant Psychology 31: 15-30. [CrossRef]

Deykin, Eva, Patricia Patti, and Jon Ryan. 1988. Fathers of adopted children: A study of the impact of child surrender on birth fathers. American Journal of Orthopsychiatry 58: 240-48. [CrossRef]

Edelstein, Robin, Britney Wardecker, William Chopik, Amy Moors, Emily Shipman, and Natalie Lin. 2015. Prenatal Hormones in First-Time Expectant Parents: Longitudinal Changes and Within-Couple Correlations. American Journal of Human Biology 27: 317-25. [CrossRef] 
Gadd, Jeremy. 2003. Book review. In Reaching Out. Newsletter: The Benevolent Society.

Gair, Susan, and Sharon Moloney. 2013. Broadening notions of 'missing persons' to increase social inclusion, public empathy and healing: Considering the case of children missing through adoption. Journal of Social Inclusion 4: 1.

Gediman, Judith, and Linda Brown. 1991. Birth Bond: Reunions between Birth Parents and Adoptees, What Happens After. Far Hills: New Horizon Press.

HM Passport Office. 2019. Part II of the Adoption Contact Register for England and Wales, birth parent registrations. Personal communication.

Howe, David, Phillida Sawbridge, and Diana Hinings. 1992. Half a Million Women: Mothers Who Lose Their Children by Adoption. London: Penguin.

Hubin, Donald. 2014. Fractured Fatherhood: An Analytic Philosophy Perspective on Moral and Legal Paternity. Journal of Family Theory E Review 6: 76-90.

Hughes, Elizabeth. 2015. "There's No Such Thing as a Whole Story": The Psychosocial Implications of Adopted Women's Experiences of Finding Their Biological Fathers in Adulthood. Studies in Gender and Sexuality 16: 151-69. [CrossRef]

Hughes, Beverley, and Janette Logan. 1993. Birth Parents: The Hidden Dimension. Manchester: University of Manchester.

Jones, Christine, and Simon Hackett. 2012. Redefining Family Relationships Following Adoption: Adoptive Parents' Perspectives on the Changing Nature of Kinship between Adoptees and Birth Relatives. The British Journal of Social Work 42: 283-99. [CrossRef]

Kenny, Pauline, Daryl Higgins, Carol Soloff, and Reem Sweid. 2012. Past Adoption Experiences: National Research Study on the Service Response to Past Adoption Practices. Canberra: Australian Institute of Family Studies/Australian Government.

Khambatta, Anisha. 2011. An exploratory study of adoptive fatherhood: Biological relatedness, father-child attachment, stress and coping. Australian Journal of Adoption 3: 2.

Lamb, Michael. 2010. The Role of the Father in Child Development, 5th ed. Hoboken: Wiley.

Lewis, Shirley, and Geraldine Brady. 2018. Parenting under Adversity: Birth Parents' Accounts of Inequality and Adoption. Social Sciences 7: 257. [CrossRef]

Logan, Janette. 1996. Birth Mothers and their Mental Health: Uncharted Territory. British Journal of Social Work 26: 609-25. [CrossRef]

Machin, Anna. 2018. The Life of Dad: The Making of a Modern Father. London: Simon \& Schuster.

Mahowald, Mary. 2000. Genes, clones and gender equality. DePaul Journal of Health Care Law 3: 495-526.

March, Karen. 1995. The Stranger Who Bore Me: Adoptee-Birth Mother Relationships. Toronto: University of Toronto Press.

Mason, Mary. 1995. Out of the Shadows: Birthfathers' Stories. Edina: O.J. Howard Publishing.

Neil, Elspeth. 2017. Helping Birth Parents in Adoption a Literature Review of Birth Parent Support Services, Including Supporting Post Adoption Contact. Munchen: Deutsches Jugendinstitut e.V. Abteilung Familie und Familienpolitik.

O'Halloran, Karen. 2015. 'The Changing Face of Adoption in the United Kingdom'. In The Politics of Adoption. New York: Springer, chp. 2.

Passmore, Nola, and Heather Chipuer. 2009. Female Adoptees' Perceptions of Contact with Their Birth Fathers: Satisfactions and Dissatisfactions with the Process. American Journal of Orthopsychiatry 79: 93-102. [CrossRef]

Passmore, Nola, and Gary Coles. 2009. Birth Fathers' Perspectives on Reunions with Their Relinquished Children [online]. In Connecting Research and Practice in Relationships: Conference Proceedings. Melbourne: Australian Psychological Society, pp. 35-41.

Passmore, Nola, and Judith Feeney. 2009. Reunions of Adoptees Who Have Met Both Birth Parents: Post-Reunion Relationships and Factors that Facilitate and Hinder the Reunion Process. Adoption Quarterly 12: 100-19. [CrossRef]

Plantin, Lars, Sven-Axel Månsson, and Jeremy Kearney. 2003. Talking and doing fatherhood: on fatherhood and masculinity in Sweden and England. Fathering: A Journal of Theory, Research, and Practice about Men as Fathers 1: 3-26. [CrossRef]

Ranson, Gillian. 2015. Fathering, Masculinity and the Embodiment of Care. Basingstoke: Palgrave Macmillan. 
Rawles, Simon. 2003. From Here To Paternity. The Observer Magazine, pp. 80-81. Available online: https://www.theguardian.com/society/2003/oct/26/adoptionandfostering.adoption (accessed on 21 March 2019).

Robinson, Evelyn. 2018. Adoption and Loss. Christies Beach: Clova Publications.

Ryburn, Murray. 1995. Secrecy and Openness in Adoption: An Historical Perspective. Social Policy E Administration 29: 150-68.

Siegel, Deborah. 2017. Fatherhood and Adoption. In Fatherhood in America: Social Work Perspectives on a Changing Society. Springfield: Charles C. Thomas.

Smeeton, Joe, and Kathy Boxall. 2011. Birth parent's perceptions of professional practice in child care and adoption proceedings: implications for practice. Child E Family Social Work 16: 444-53.

Trinder, Liz, Feast Julia, and David Howe. 2004. The Adoption Reunion Handbook. Chichester: John Wiley and Sons. Triseliotis, John, Julia Feast, and Fiona Kyle. 2005. The Adoption Triangle Revisited. London: BAAF.

Turner, Barry, and Tony Rennel. 1995. When Daddy Came Home: How Family Life Changed Forever in 1945. London: Hutchinson.

Ward, Andrew. 2012. The Birth Father's Tale. London: CoramBAAF.

Witney, Celia. 2004. Original fathers: An exploration into the experiences of birthfathers involved in adoption in the mid-20th century. Adoption \& Fostering 28: 52-61.

Yngvesson, Barbara. 2007. Refiguring Kinship in the Space of Adoption. Anthropological Quarterly 80: 561-79. [CrossRef]

(C) 2019 by the author. Licensee MDPI, Basel, Switzerland. This article is an open access article distributed under the terms and conditions of the Creative Commons Attribution (CC BY) license (http:/ / creativecommons.org/licenses/by/4.0/). 